\title{
Assessment of the Quality and Reliability of the Information on Bone Tumor on Youtube
}

\section{Kemik Tümörleri ile Alakalı Youtube Videolarının Kalite ve Güvenilirlik Analizi}

\section{(D) Sezgin Bahadır Tekin1, (D Erman Öğümsöğütlü²}

${ }^{1}$ Dr. Ersin Arslan Training and Research Hospital, Clinic of Orthopedic Surgery, Gaziantep, Turkey

${ }^{2}$ Gaziantep University Faculty of Medicine, Department of Orthopedic Surgery, Gaziantep, Turkey

\section{Abstract}

Objective: Our aim is to assess the content quality and reliability of Youtube videos on bone tumors.

Method: We searched Youtube using the keyword "bone tumors," and included the first 50 videos listed in our study. Two orthopedic surgeons analyzed the videos, and then, we examined them in terms of length, number of views and likes, and source. To evaluate their content quality, the Global Quality score (GQS) (0-4), Journal of the American Medical Association (JAMA) (0-5), and DISCERN (15-75) scoring systems were used; based on these, the obtained data were statistically analyzed.

Results: Of the 50 videos analyzed, four ( $8 \%)$ included animation, while 46 (92\%) did not; 12 (24\%) were uploaded by doctors, 23 (46\%) by health channels, $10(20 \%)$ by universities, three (6\%) by clinics, and one (2\%) each by a hospital and a trainer. The average video length was 16 minutes and 18 seconds (38-6.088 seconds), average number of views was 14,856.24, and average number of likes was 130.50 (1-1448). The mean scores of GQS, JAMA, and DISCERN were 2.22 (1-4), 2.12 (1-3), and 33.48 (15-75), respectively. There was no statistical significance in the scores and video length, or the number of likes and views between the two researchers.

Conclusion: Youtube videos on bone tumors have low content quality. Improvement of the same will help dispense correct information to patients, so that they can continue their treatment. We believe that patient treatment compliance can be increased by accelerating the patient's preparation and adaptation process for treatment with accurate information.

Keywords: Bone tumors, video analysis, video quality, youtube

\section{Öz}

Amaç: Çalışmanın amacı Youtube'daki kemik tümörleri ile alakalı videoların kalitesini ve güvenilirliğini değerlendirmektir.

Yöntem: Youtube arama sekmesine anahtar kelime olan 'bone tumors' yazılarak ilk çıkan 50 video çalışmaya dahil edildi. Videolar iki ortopedik cerrah tarafından analiz edildiler. Tüm videolar uzunluk, izlenme sayısı, like sayısı ve videonun kaynağı bilgileri ile analiz edildiler. Videoların kalitesini değerlendirmek için Global Kalite skoru (GKS) (score range: 0-4), Journal of the American Medical Association (JAMA) (0-5) ve DISCERN (15-75) skorlama sistemleri kullanıldı. Elde edilen veriler bu skorlama sistemlerine göre istatistiksel olarak analiz edildiler.

Bulgular: Analiz edilen 50 videodan 4 (\%8) video animasyon içeriyorken 46 (\%92) video ise içermiyordu, 12 (\%24) video hekimler, 23 (\%46) video sağlık kanalı, 10 (\%20) video üniversite, 3 (\%6) video klinik, 1 (\%2) video hastane, 1 (\%2) video ise trainer tarafından eklenmişti. Ortalama video uzunluğu 16 dakika 18 saniye (38-6,088 saniye), ortalama izlenme sayısı 14856,24 (41-84,253), ortalama like sayısı 130,50 (1-1,448) idi. Ortalama GKS skoru 2,22 (1-4), ortalama JAMA 2,12 (1-3), ortalama Discern skoru ise 33,48 (17-66) idi. Her iki araştırmacı arasında skorlama sistemleri ve video uzunluğu, beğeni sayısı ve izlenme oranları açısından istatistiksel olarak fark yoktu.

Sonuç: Kemik tümörleri ile alakalı Youtube videolarının kalitesi düşüktür. Bu durum iyileştirilerek malignitesi olan hastalara daha doğru enformasyon sağlanabilir ve hastalar daha doğru bilgilerle tedavi süreçlerini devam ettirebilirler.

Anahtar kelimeler: Kemik tümörleri, video analizi, video kalitesi, youtube

Address for Correspondence: Sezgin Bahadır Tekin, Dr. Ersin Arslan Training and Research Hospital, Clinic of Orthopedic Surgery, Gaziantep, Turkey E-mail: sezginbahadirtekin@gmail.com ORCID: orcid.org/0000-0003-4740-9949 Received: 13.07.2020 Accepted: 19.08.2020

Cite this article as: Tekin SB, Öğümsöğütlü E. Assessment of the Quality and Reliability of the Information on Bone Tumor on Youtube. Bagcilar Med Bull 2020;5(3):133-137

${ }^{\circ}$ Copyright 2020 by the Health Sciences University Turkey, Bagcilar Training and Research Hospital Bagcilar Medical Bulletin published by Galenos Publishing House. 


\section{Introduction}

In today's times, Internet is the easiest way to access information. A majority of people refer to sources online to obtain information prior to their medical applications, as well as in other areas. Video sharing sites such as YouTube have become very popular in this respect.

More than 1.9 billion people visit Youtube every month and can find a huge number of medical education videos (1). Patients frequently visit the platform and benefit from its rich video archive while trying to gather information about their diseases (2-5).

Those suffering from orthopedic disorders are among these patients. In particular, patients with suspected malignancy are more anxious and may need a more comprehensive search; they may increase their levels of anxiety by constantly thinking the worst and referring to the most unfavorable examples online. Our Google search for "bone tumors" on March 10, 2020 yielded 62 million results, which may be an indication for that this particular search is very popular. However, studies show that the content quality of health information videos online is low (6). In order for people to access more accurate information, videos with better quality content on health information are needed (7).

Bone tumors can be perceived in various ways, and because patients suspect of having them and worry, they conduct online searches.

Thus, the purpose of our study was to evaluate the content quality of Youtube videos on bone tumors for those who want accurate information.

\section{Materials and Methods}

We did a search on Youtube using the keyword "bone tumors" on March 10, 2020 and included the first 50 videos that were listed in our study. Videos in English that were repeated and those that comprised only product advertisements and not related to bone tumors were excluded.

The videos were analyzed by two independent orthopedic surgeons. We recorded information on the videos' length, number of views and likes, and the source (i.e., the uploader), and then scored them using the Global Quality score (GQS), Journal of the American Medical Association (JAMA) and DISCERN scoring systems to evaluate their content quality (8-10) (Figure 1,2) (Table $1)$.
Scoring was done by taking the means of the scores provided by both surgeons. The GQS is a system that scores between 0 and 4 , from the lowest quality to the most quality. The JAMA scoring system comprises four criteria, each scored either 0 or 1 , adding up to a maximum of 5 points and a minimum of 0 to measure the content quality of the videos. The DISCERN scoring system comprises 15 questions; its scores between 63 and 75 points are classified as "excellent," 51 and 62 as "good," 39 and 50

Section 1 - Is the publication reliable?

1. Are the aims clear?

2. Does it achieve its aims?

3. Is it relevant?

4. Is it clear what sources of information were used to compile the publication?

5. Is it clear when the information used in the publication was produced?

6. Is it balanced and unbiased?

7. Does it provide details of additional sources of support and information?

8. Does it refer to areas of uncertainty?

Section 2 - How good is the quality of information?

9. Does it describe how alcohol affects the fetus?

10. Does it describe any benefits for reducing alcohol use in pregnancy?

11. Does it describe the risks?

12. Does it describe the role of other lifestyle factors?

13. Does it provide alternatives to drinking alcohol?

14. Does it provide support for shared decision-making?

Section 3 - Overall rating of the publication

15. Based on the answers to all of the above questions, rate the overall quality of the publication as a source of information about treatment choices

Figure 1. Discern scoring system 
as "average," 28 and 38 as "poor," and $<28$ as "very poor." Higher scores obtained from the scale indicate a higher quality of information. This study does not contain any human or animal resources, ethical approval was not needed for this study.

\section{Statistical Analysis}

The Shapiro-Wilk test was conducted to evaluate the fitness of the numerical variables to a normal distribution, and then, the Mann-Whitney $U$ test to compare the non-normally distributed variables in two independent groups. Relationships between the variables that were not normally distributed were analyzed using the Spearman's rank correlation coefficient. The SPSS 22.0 Windows software package was used for the analyses. For all analyses, $\mathrm{p}<0.05$ was considered as statistically significant.

\begin{tabular}{lll}
$\begin{array}{l}\text { Table 1. JAMA scoring system } \\
\text { JAMA scoring system rating section }\end{array}$ & No & Yes \\
\hline $\begin{array}{l}\text { Authorship authors and contributors, their affiliations, } \\
\text { and relevant credentials should be provided }\end{array}$ & 0 & 1 \\
$\begin{array}{l}\text { Attribution references and sources for all content should } \\
\text { be listed clearly, and all relevant copyright information } \\
\text { should be noted }\end{array}$ & 0 & 1 \\
$\begin{array}{l}\text { Disclosure website "ownership" should be prominently } \\
\text { and fully disclosed, as should any sponsorship }\end{array}$ & 0 & 1 \\
$\begin{array}{l}\text { Advertising, underwriting, commercial funding } \\
\text { arrangements or support, or potential conflicts of Interest }\end{array}$ & & \\
$\begin{array}{l}\text { Currency dates when content was posted and updated } \\
\text { should be indicated }\end{array}$ & 0 & 1 \\
\hline
\end{tabular}

JAMA: Journal of the American Medical Association

\section{Score Global score description}

1 Poor quality, poor flow of the site, most information missing, not at all useful for patients

2 Generally poor quality and poor flow, some information listed but many important topics missing of very limited use to patients

3 Moderate quality, suboptimal flow, some important information is adequately discussed but others poorly discussed, somewhat useful for patients

4 Good quality and generally good flow, most of the relevant information is listed, but some topics not covered, useful for patients

$5 \quad$ Excellent quality and excellent flow, very useful for patients

Figure 2. Global Quality score

\section{Results}

Of the 50 videos analyzed, four (8\%) included animation, while 46 (92\%) did not; 12 (24\%) were uploaded by doctors, $23(46 \%)$ by health channels, $10(20 \%)$ by universities, four $(8 \%)$ by clinics, and one (2\%) each by a hospital and a trainer. The average video length was 16 minutes and 18 seconds (38-6.088 seconds), the average number of views was $14,856.24$, and the average number of likes was 130.50 (1-1.448). The mean scores of GQS, JAMA, and DISCERN scoring systems were 2.22 (1-4), 2.12 (1-3), and 33.48 (17$66)$, respectively (Table 2 ).

The statistical analysis showed a positive, medium correlation between the video length and GQS score ( $p=0.001$ ), and a positive, weak correlation between the video length and GQS and DISCERN scores $(\mathrm{p}=0.000$ / $\mathrm{p}=0.006$ ). There were no statistically significant differences between the video length and JAMA score $(\mathrm{p}=0.978)$.

There was a significant correlation between the number of views and GQS and DISCERN scores, but not between the number of views and JAMA score $(\mathrm{p}=0.049 / \mathrm{p}=0.079 /$ $\mathrm{p}=0.038$ ).

There was no significant correlation between the number of likes and GQS, JAMA, and DISCERN scores ( $\mathrm{p}=0.058$ / $\mathrm{p}=0.067 / \mathrm{p}=0.071)$. The statistical analyses are summarized in Table 3.

On the other hand, with respect to the videos uploaded by doctors, the length $(\mathrm{p}=0.012)$, number of views $(\mathrm{p}=0.025)$,

\begin{tabular}{llll}
\multicolumn{3}{l}{ Table 2. Scores of videos according to scoring systems } \\
$\begin{array}{l}\text { Scoring } \\
\text { systems }\end{array}$ & $\begin{array}{l}\text { Global Quality } \\
\text { scores }\end{array}$ & JAMA & DISCERN \\
\hline Scores & $2.22(1-4)$ & $2.12(1-3)$ & $33.48(17-66)$ \\
\hline
\end{tabular}

JAMA: Journal of the American Medical Association

Table 3. Statistical analysis of data

\begin{tabular}{|c|c|c|c|c|}
\hline & \multicolumn{4}{|c|}{ Correlations } \\
\hline & & $\begin{array}{l}\text { Video } \\
\text { length }\end{array}$ & $\begin{array}{l}\text { Number } \\
\text { of views }\end{array}$ & Likes \\
\hline & r & 0.533 & 0.280 & 0.269 \\
\hline \multirow[t]{3}{*}{ GQS } & p & 0.000 & 0.049 & 0.058 \\
\hline & $\mathrm{n}$ & 50 & 50 & 50 \\
\hline & r & 0.004 & 0.079 & -0.062 \\
\hline \multirow[t]{3}{*}{ JAMA } & p & 0.978 & 0.586 & 0.667 \\
\hline & $\mathrm{n}$ & 50 & 50 & 50 \\
\hline & $r$ & 0.382 & 0.295 & 0.258 \\
\hline \multirow[t]{2}{*}{ DISCERN } & p & 0.006 & 0.038 & 0.071 \\
\hline & $\mathrm{n}$ & 50 & 50 & 50 \\
\hline
\end{tabular}

GQS: Global Quality scores, JAMA: Journal of the American Medical Association 
number of likes ( $\mathrm{p}=0.003$ ), and JAMA scores $(\mathrm{p}=0.011$ ) were significantly higher than those of videos uploaded by other sources. The JAMA scores of videos uploaded by health channels were significantly higher than those of videos uploaded by universities $(\mathrm{p}=0.001)$.

There were no significant differences about scoring system between two surgeons. $(\mathrm{p}=0.012)$.

\section{Discussion}

Our study shows that the content quality of Youtube videos on bone tumors, searched using the keyword "bone tumors," is low.

This study is the first to focus on orthopedic malignancies, and it provides information on the effects of video content quality on patients. Of the 50 videos reviewed, 12 were uploaded by doctors, 23 by health channels, 10 by universities, four by clinics, and one each by a hospital and a trainer. This indicates that the topic is addressed mostly by professionals. Although a literature review has shown that video uploading by patients is done at a level that cannot be underestimated, in our study, health professionals are prominent (11).

The mean video length in our study was 16.18 minutes. Previous studies have shown a range of 6.17-10.35 minutes $(12,13)$, which means that our mean was higher.

Furthermore, in our study, the length, number of views and likes, and JAMA scores of videos uploaded by doctors were higher than those uploaded by other sources. This indicates that the doctors' videos are of a higher quality in terms of content. This may indicate that the videos uploaded by doctors are more scientific.

Several scoring systems have been used in the literature to determine the content quality of Youtube videos $(14,15)$, we used three- GQS, JAMA, and DISCERN- and our data analysis revealed their scores as $2.22,2.12$, and 33.48 , respectively. Thus, the mean scores according to these systems correlate with low content quality. Previous studies have compared this with the source of videos, showing that those uploaded by clinicians had high content quality (16). However, for most of the videos reviewed in our study, which were uploaded by health professionals, we did not find it relevant to make such a comparison.

There was no significant correlation between the number of likes and scores. This shows that the likes do not correlate with the content quality of the video, and there are other studies showing that videos of low content quality have more likes $(17,18)$.

The selection of this topic is based on the consideration that cancer patients may want to do more research on their diseases. This is because malignancies are always a matter of curiosity for patients- they are stressed because of their illness and feel the need to gather more information. It is known that Youtube videos with low content quality negatively affect the patient-doctor relationship (19). Additionally, a literature search on Youtube videos related to other malignancies reveals that there is no study focusing on bone tumors (20). Orthopedic studies in the literature focusing on quality assessment of Youtube videos are limited in number. These are on scoliosis, femoroacetabular impingement, hip arthritis, anterior cruciate ligament injury, and reconstruction (21-24) among other topics. However, there is a lack of studies on orthopedic malignancies. Therefore, we contribute to the literature by studying the content quality of videos on bone tumors and reporting that patients who are curious about this topic receive information from videos with low content quality.

While our method of selecting and analyzing the first 50 videos in the search list can be considered a limitation, it should be noted that there are studies in the literature that have conducted similar types of evaluations $(25,26)$. In addition, considering that patients watch those videos that show up first in search results, the number of our videos is acceptable. Doing the search on different days and performing the assessment at different times would have been another limitation; hence, to prevent that, both of us completed our analyses on the same day.

In this study, the all videos related to bone tumors were analyzed by two independent surgeons. All videos rated by surgeons got close scores in the scoring system. One of our main goals here was to demonstrate that videos got the same results by all surgeons watching.

The dissemination of accurate and reliable information regarding the "bone tumors" may also play a significant role in educating patients and optimizing outcomes. More accurate information about the bone tumors can have a positive impact on patient outcomes in a multifactorial manner. If patients are properly informed, they will be more likely to seek timely treatment, and better outcomes may ensue.

In sum, a majority of the Youtube videos on bone tumors have low content quality, which may become patients' 
primary source of information due to easy access to videos. Thus, improving the content quality of videos would be beneficial for both patients and health professionals. Our study is the first to assess the content quality of Youtube videos on bone malignancies, and further research is needed on this topic.

\section{Ethics}

Ethics Committee Approval: This study does not contain any human or animal resources, ethical approval was not needed for this study.

Informed Consent: No patients data were used.

Peer-review: Externally peer-reviewed.

\section{Authorship Contributions}

Concept: S.B.T., Design: S.B.T., Data Collection or Processing: E.Ö., Analysis or Interpretation: S.B.T., Writing: S.B.T.

Conflict of Interest: No conflict of interest was declared by the authors.

Financial Disclosure: The authors declared that this study received no financial support.

\section{References}

1. Statistics for YouTube, https://www.youtube.com/yt/press. Accessed April 23, 2019.

2. Drozd B, Couvillon E, Suarez A. Medical YouTube videos and methods of evaluation: literature review. JMIR Med Educ 2018;4(1):e3.

3. Erdem MN, Karaca S. Evaluating the accuracy and quality of the information in kyphosis videos shared on YouTube. Spine (Phila Pa 1976) 2018;43(22):E1334-E1339.

4. Staunton PF, Baker JF, Green J, Devitt A. Online curves: a quality analysis of scoliosis videos on YouTube. Spine (Phila Pa 1976) 2015;40(23):1857-1861.

5. Samuel N, Alotaibi NM, Lozano AM. YouTube as a source of information on neurosurgery. World Neurosurg 2017;105:394-398.

6. Kunst H, Groot D, Latthe MP, Latthe M, Khan KS. Accuracy of information on apparently credible websites: survey of five common health topics. BMJ 2002;324(7337):581-582.

7. AbouZahr C, Boerma T. Health information systems: The foundations of public health. Bull World Health Organ 2005;83(8):578-583.

8. Silberg WM, Lundberg GD, Musacchio RA. Assessing, controlling and assuring the quality of medical information on the Internet: Caveant lector et vieworeLet the reader and viewer beware. JAMA 1997;277(15):1244-1245.

9. Charnock D, Shepperd S, Needham G, Gann R. DISCERN: an instrument for judging the quality of written consumer health information on treatment choices. J Epidemiol Community Health 1999;53(2):105-111.
10. Weil AG, Bojanowski MW, Jamart J, Gustin T, Lévêque M. Evaluation of the quality of information on the Internet available to patients undergoing cervical spine surgery. World Neurosurg 2014;82(1-2):e31-e39.

11. Cassidy JT, Baker JF. Orthopaedic patient information on the World Wide Web: an essential review. J Bone Joint Surg Am 2016;98(4):325338.

12. Madathil KC, Rivera-Rodriguez AJ, Greenstein JS, Gramopadhye AK. Healthcare information on YouTube: a systematic review. Health Informatics J. 2015;21(3):173-94.

13. Gokcen HB, Gumussuyu G. A quality analysis of disc herniation videos on YouTube. World Neurosurg 2019; S1878-8750(19)3024330246.

14. Ovenden CD, Brooks FM. Anterior cervical discectomy and fusion YouTube videos as a source of patient education. Asian Spine J 2018;12:(6)987-991.

15. Fat MJL, Doja A, Barrowman N, Sell E. YouTube videos as a teaching tool and patient resource for infantile spasms. J Child Neurol 2011;26(7):804-809.

16. Tartaglione JP, Rosenbaum AJ, Abousayed M, Hushmendy SF DiPreta JA. Evaluating the quality, accuracy, and readability of online resources pertaining to hallux valgus. Foot Ankle Spec 2016;9(1):17-23

17. Kumar N, Pandey A, Venkatraman A, Garg N. Are video sharing web sites a useful source of information on hypertension? J Am Soc Hypertens 2014;8(7):481-490.

18. LeeJS, Seo HS, Hong TH. YouTube as a source of patient information on gallstone disease. World J Gastroenterol 2014;20(14):4066-4070.

19. Madathil KC, Rivera-Rodriguez AJ, Greenstein JS, Gramopadhye AK. Healthcare information on YouTube: a systematic review. Health Informatics J 2015;21(3):173-194.

20. Cooper CP, Gelb CA, Chu J. Gynecologic Cancer Information on Youtube: Will Women Watch Advertisements to Learn More? J Cancer Educ 2016;31(3):602-604.

21. Cassidy JT, Fitzgerald E, Cassidy ES, Cleary M, Byrne DP, Devitt $\mathrm{BM}$, et al. YouTube provides poor information regarding anterior cruciate ligament injury and reconstruction. Knee Surg Sports Traumatol Arthrosc 2018;26(3):840-845.

22. Staunton PF, Baker JF, Green J, Devitt A. Online curves: a quality analysis of scoliosis videos on YouTube. Spine (Phila Pa 1976) 2015;40(23):1857-1861.

23. MacLeod MG, Hoppe DJ, Simunovic N, Bhandari M, Philippon MJ, Ayeni OR. YouTube as an information source for femoroacetabular impingement: a systematic review of video content. Arthroscopy 2015;31(1):136-142.

24. Fischer J, Geurts J, Valderrabano V, Hügle T. Educational quality of YouTube videos on knee arthrocentesis. J Clin Rheumatol 2013;19(7):373-376.

25. Morahan-Martin JM. How internet users find, evaluate, and use online health information: a cross-cultural review. Cyberpsychol Behav 2004;7(5):497-510.

26. Kucukakkas O, Atar E, Berberoglu AH, Karaman CA, Korkmaz MB. (2019). YouTube as an information source for intra-articuler knee injection. Annals of Medical Research 2019;26(5)918-923. 